\title{
EARTHQUAKE DAMAGE EVALUATION OF AN 8-STORY STEEL-REINFORCED CONCRETE BUILDING USING $S_{a}-S_{d}$ CURVES \\ $\mathrm{SRC}$ 建物の建物性能曲線による地震損傷評価
}

\author{
Ligang LI* , Akihiro NAKAMURA** , Toshihide KASHIMA*** \\ and Masaomi TESHIGAWARA**** \\ 李 立 岗, 中 村聡宏, 鹿 嶋 俊 英, 勅使川原正臣
}

\begin{abstract}
A seismic performance curve shows the relationship between the representative displacement $\left(S_{d}\right)$ and the equivalent base shear force coefficient $\left(S_{a}\right)$ of a structure. The seismic capacity of a building can be assessed in a straightforward manner using a simple $S_{a}-S_{d}$ performance skeleton curve. In this study, earthquake response records were used to obtain $S_{a}-S_{d}$ curves for a steel-reinforced concrete (SRC) building and assess the changes in the seismic performance of the building that occur during an earthquake.

This paper compares the seismic performance curves of an 8-story SRC building for 27 strong earthquakes that occurred in Japan between 1998 and 2012. The results demonstrate the practicability of using $S_{a}-S_{d}$ curves to evaluate the damage to real buildings using data collected during strong earthquakes.
\end{abstract}

\section{Keywords: Fundamental frequency, Performance curve, SRC building, Strong earthquake records, Wavelet transform technique \\ 固有周波数，性能曲線，鉄筋コンクリート，強震記録，ウェーブレット変換}

\section{Introduction}

Rapid and quantitative evaluation of earthquake damage is important for seismic retrofit and avoidance of secondary hazards caused by aftershocks. Recent advances in the technology used in accelerometers have made good-quality measurement data available for this purpose. The data recorded by seismic accelerometers installed in buildings have been used in damage evaluation. In addition, damage evaluation methods have been developed to identify both the location and the degree of damage. In general, earthquake damage detection methods are based on monitoring changes in the dynamic characteristics (vibration frequency and modal shapes) of structures ${ }^{1)}$.

However, it is difficult to understand how the fundamental frequency and seismic capacity of a structure change during an earthquake using methods based on dynamic characteristics. The fundamental frequency does not always reliably reflect the damage condition of a building due to a specific earthquake. Changes in the fundamental frequency are influenced by many factors, such as soil-structure interaction (SSI) effects ${ }^{2)}$ and the local weather ${ }^{3)}$ (high temperature, heavy rainfall, and wind). A reduction in the fundamental frequency has been observed even in cases when no damage could be detected with a vibration test ${ }^{3)}$, 4). Furthermore, modal shapes are not reliable for use in damage detection $^{1)}$.

In recent years, a new type of earthquake damage detection method based on wavelet technology and wave propagation has been developed by Maria I. Todorovska and Mihailo D. Trifunac ${ }^{5)}$, 6), 7). In this method, a building is modeled as a layered shear beam, and structural damage can be detected from the distribution of shear and torsional wave velocities, which can be directly related to the structural rigidity along the building's height. The advantages of this method, including its robustness and insensitivity to SSI effects and local weather, over methods based on monitoring changes in the dynamic characteristics have been well described ${ }^{8}$.

An earthquake damage evaluation method based on the $S_{a}-S_{d}$ curve (seismic performance curve) concept was developed recently. This method uses wavelet transform

\footnotetext{
* Ph. D. Candidate, Graduate School of Environmental Studies, Nagoya University

** Assist. Prof., Graduate School of Environmental Studies, Nagoya University, Dr. Eng.

*** Senior Research Engineer, Building Research Institute, Dr. Eng.

**** Prof., Graduate School of Environmental Studies, Nagoya University, Dr. Eng. (Visiting Research Engineer, Building Research Institute)
}

名古屋大学大学院環境学研究科 博士後期課程

名古屋大学大学院環境学研究科 助教・博士 (工学)

独立行政法人建築研究所 主任研究員・博士 (工学)

名古屋大学大学院環境学研究科 教授 $\cdot$ 工博

(独立行政法人建築研究所 客員研究員) 
technology (WTT) to extract the fundamental mode responses of a structure9). The effectiveness of the $S_{a}-S_{d}$ curve approach to assessing the damage caused by large structural deformations has been confirmed in a shaking table test. The measured performance curve largely agreed with the computed curve calculated using $\mathrm{WTT}^{10}$. In contrast to traditional dynamic characteristics-based methods, the $S_{a}-S_{d}$ curve method was found to be able to detect changes in the fundamental frequency from small responses to the maximum response and to identify the seismic capacity points of the measured building.

However, there has been little applied research on how to use $S_{a}-S_{d}$ curves to evaluate the seismic capacity of real steel-reinforced concrete (SRC) buildings. In the paper, we present an evaluation strategy for using $S_{a}-S_{d}$ curves to evaluate the seismic capacity of real buildings and the damage suffered by such buildings in real earthquakes. We also describe how to use $S_{a}-S_{d}$ curves to explain and evaluate changes in the fundamental frequency of a real building-the Building Research Institute (BRI) annex building (an 8-story SRC building) using earthquake response measurement data.

\section{The case study}

\subsection{BRI ANNEX building}

The BRI annex building is an eight-story SRC building with a base floor underground (B1F). The building is supported by a gravity foundation and connected to the main building through a nonstructural passageway, as shown in Figure 1(a). The height of the building (from the ground level to the $8^{\text {th }}$ floor) is $28 \mathrm{~m}$, and the depth of the underground portion is $8.5 \mathrm{~m}$. An instrument cabin consisting of a steel structure is located on the $8^{\text {th }}$ floor. The building is instrumented with 11 accelerometers, each of which can record accelerations in 3 directions: east-west (taken here to be the $\mathrm{X}$ direction), north-south (the $\mathrm{Y}$ direction), and up-down (the $\mathrm{Z}$ direction). The locations of the measurement points in the building are shown in Figures 1(b) and 1(c).

The responses of the BRI annex building to seismic activity have been monitored since it was built in 1998. Kashima et al. 11), 12) carried out a series of studies on the SSI effects, ground motion and dynamic characteristics of the building, using earthquake response measurement data. The findings from these studies can be summarized as follows: (a) the rocking effect $(8-11 \%)$ is much larger than the swaying effect $(2-3 \%)$, (b) the fundamental frequency of the building decreased to $70 \%$ of its initial value between 1998 and 2005, and (c) the decrease in the fundamental frequency was due to degradation of the superstructure's stiffness. However, the research did not explain the reason for the degradation of the superstructure's stiffness, such whether the building experienced structural damage during earthquakes that occurred between 1998 and 2005. In this research, we try to use $S_{a}-S_{d}$ curves to answer this question. 2.2 Earthquake response records

A total of 1,239 earthquake records were collected for the annex building between 1998 and 2012. During the same period, 141 earthquakes with peak ground accelerations (PGA) greater than $10 \mathrm{Gal}$ and Japanese Meteorological Agency intensities (IJMA) greater than 1 degree occurred in Japan. In this paper,

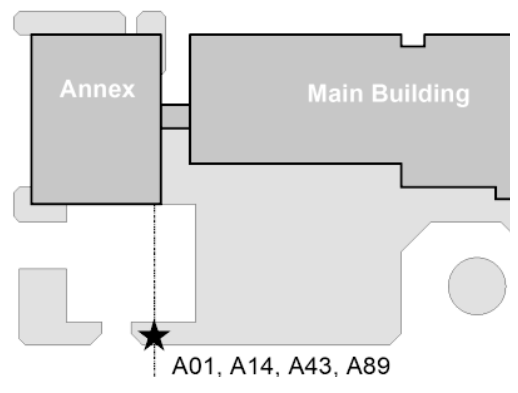

(a) Diagram of the building footprint

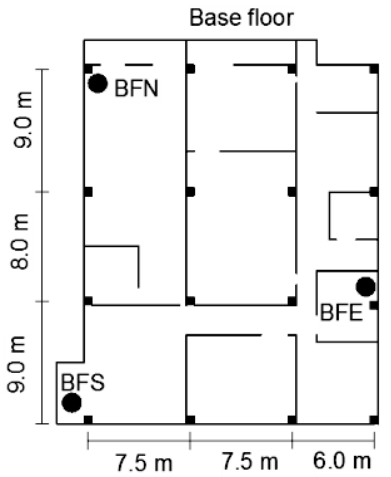

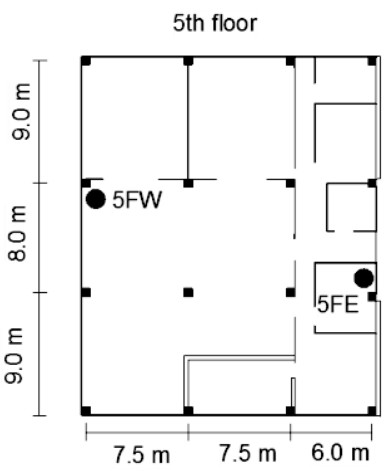

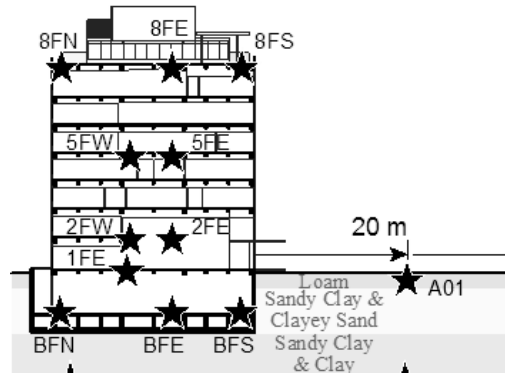

(b) Elevation diagram of the measurement points in the building 5 th floor

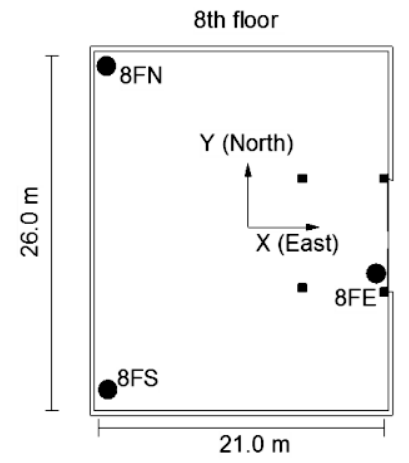

(c) Configuration of the measurement points on floors

Fig. 1 Measurement points in the building 
Table 1 Strong earthquakes that occurred in Japan between 1998 and 2012

\begin{tabular}{|c|c|c|c|c|c|c|c|c|c|c|}
\hline \multirow{2}{*}{ Time } & \multirow{2}{*}{ Epicenter } & \multirow{2}{*}{ Latitude } & \multirow{2}{*}{ Longitude } & \multirow{2}{*}{$\begin{array}{r}\text { Depth } \\
(\mathrm{Km})\end{array}$} & \multirow{2}{*}{$\begin{array}{c}\mathrm{M} \\
\text { (Degree) }\end{array}$} & \multirow{2}{*}{$\begin{array}{l}\text { Dist. } \\
(\mathrm{Km})\end{array}$} & \multirow{2}{*}{$\begin{array}{l}\text { PGA } \\
\text { (gal) }\end{array}$} & \multirow{2}{*}{$\begin{array}{c}\text { IJMA } \\
\text { (Degree) }\end{array}$} & \multicolumn{2}{|c|}{ Fundamental response } \\
\hline & & & & & & & & & E-W & $\mathrm{N}-\mathrm{S}$ \\
\hline $1998 / 06 / 2423: 52$ & S Ibaraki Pref. & 140.1017 & 36.1500 & 68 & 4.7 & 3 & 19.3 & 2.6 & rank5 & rank5 \\
\hline $1998 / 08 / 2908: 46$ & Tokyo Bay & 140.0317 & 35.6283 & 65 & 5.2 & 56 & 10.1 & 2.1 & rank5 & rank5 \\
\hline 1999/03/26 08:31 & N Ibaraki Pref. & 140.6183 & 36.4467 & 59 & 5.0 & 60 & 46.3 & 3.2 & rank5 & rank5 \\
\hline $1999 / 04 / 2521: 27$ & N Ibaraki Pref. & 140.6250 & 36.4517 & 59 & 5.2 & 61 & 36.9 & 3.1 & rank5+rank6 & rank5 \\
\hline $2000 / 04 / 1006: 30$ & S Ibaraki Pref. & 140.0633 & 36.1867 & 55 & 4.7 & 6 & 49.4 & 3.2 & rank6 & rank6 \\
\hline $2000 / 06 / 03$ 17:54 & NE Chiba Pref. & 140.7483 & 35.6850 & 48 & 6.1 & 79 & 16.1 & 2.7 & rank6 & rank5+rank6 \\
\hline $2000 / 07 / 2103: 39$ & Off Ibaraki Pref. & 141.1217 & 36.5250 & 49 & 6.4 & 104 & 37.9 & 3.4 & rank6 & rank6 \\
\hline $2003 / 05 / 2618: 24$ & Off Miyagi Pref. & 141.6533 & 38.8167 & 72 & 7.1 & 330 & 29.2 & 3.2 & rank6 & rank6 \\
\hline $2003 / 09 / 2012: 54$ & S Chiba Pref. & 140.3033 & 35.2150 & 70 & 5.8 & 104 & 13.7 & 2.8 & rank6 & rank6 \\
\hline $2004 / 10 / 0623: 40$ & S Ibaraki Pref. & 140.0917 & 35.9850 & 66 & 5.7 & 17 & 54.5 & 3.8 & rank6 & rank6 \\
\hline $2004 / 10 / 2317: 56$ & Chuetsu, Niigata Pref. & 138.8700 & 37.2883 & 13 & 6.8 & 168 & 30.9 & 3.4 & rank6 & rank6 \\
\hline $2004 / 10 / 2318: 34$ & Chuetsu, Niigata Pref. & 138.9317 & 37.3033 & 14 & 6.5 & 165 & 18.1 & 3.1 & rank6 & rank6 \\
\hline $2005 / 04 / 1107: 22$ & NE Chiba Pref. & 140.6200 & 35.7267 & 52 & 6.1 & 67 & 25.9 & 3.3 & rank6 & rank6 \\
\hline $2005 / 08 / 1611: 46$ & Off Miyagi Pref. & 142.2783 & 38.1500 & 42 & 7.2 & 298 & 29.8 & 3.3 & rank6 & rank6 \\
\hline $2005 / 10 / 1920: 44$ & Off Ibaraki Pref. & 141.0417 & 36.3817 & 48 & 6.3 & 91 & 40.2 & 3.5 & rank6 & rank6 \\
\hline 2007/07/16 10:13 & $\begin{array}{c}\text { Off Jochuetsu, Niigata } \\
\text { Pref. }\end{array}$ & 138.6083 & 37.5567 & 17 & 6.8 & 205 & 19.3 & 3.6 & rank6 & rank6 \\
\hline $2008 / 05 / 08$ 01:45 & Off Ibaraki Pref. & 141.6067 & 36.2267 & 51 & 7.0 & 138 & 49.6 & 3.6 & rank6 & rank6 \\
\hline $2008 / 06 / 1408: 43$ & S Inland Iwate Pref. & 140.8800 & 39.0283 & 8 & 7.2 & 330 & 26.2 & 3.4 & rank6 & rank6 \\
\hline $2009 / 08 / 09$ 19:55 & S Off Tokaido & 138.4033 & 33.1267 & 333 & 6.8 & 368 & 28.4 & 3.2 & rank6 & rank6 \\
\hline $2010 / 03 / 14$ 17:08 & Off Fukushima Pref. & 141.8167 & 37.7233 & 40 & 6.7 & 235 & 12.0 & 2.5 & rank6 & rank6 \\
\hline $2010 / 06 / 13$ 12:32 & Off Fukushima Pref. & 141.7950 & 37.3950 & 40 & 6.2 & 208 & 15.9 & 2.5 & rank6 & rank6 \\
\hline 2010/11/05 19:14 & S Ibaraki Pref. & 139.8417 & 36.0617 & 45 & 4.6 & 22 & 20.6 & 2.5 & rank6 & rank6 \\
\hline 2011/03/11 14:46 & Off Sanriku & 142.8600 & 38.1033 & 24 & 9.0 & 330 & 279.3 & 5.3 & rank6 & rank6+rank7 \\
\hline $2011 / 03 / 1115: 15$ & Off Ibaraki Pref. & 141.2650 & 36.1083 & 43 & 7.6 & 107 & 151.1 & 4.7 & rank6 & rank6 \\
\hline $2011 / 03 / 19$ 18:56 & N Ibaraki Pref. & 140.5700 & 36.7833 & 5 & 6.1 & 85 & 80.8 & 3.9 & rank6 & rank6 \\
\hline 2011/04/11 17:16 & $\begin{array}{l}\text { Hama-dori, Fukushima } \\
\text { Pref. }\end{array}$ & 140.6717 & 36.9450 & 6 & 7.0 & 105 & 118.1 & 4.6 & rank6+rank7 & rank6+rank7 \\
\hline 2012/03/14 21:05 & E Off Chiba Pref. & 140.9317 & 35.7467 & 15 & 6.1 & 88 & 33.3 & 3.3 & rank6+rank7 & rank6+rank7 \\
\hline
\end{tabular}

the 27 strongest of these earthquakes (see Table 1) were selected for use in the analysis. The sampling frequency of the accelerometers in the building is $100 \mathrm{~Hz}$, and displacements were calculated using the Fourier integration method in this paper.

\subsubsection{Calculation of the rocking motion}

In general, the vertical motions of two points are used to calculate the rocking angle $\left.{ }^{11)}, 13\right)$. However, in this research, three measurement points in the basement were not located on the translational axes, so the vector method, which makes use of three points, was employed to calculate the rocking angle.

As shown in Figure 1(c), BFN, BFE, and BFS are the three points on the base mat. We can calculate the following two vectors:

$$
\begin{aligned}
& \vec{p}=\overrightarrow{B F N-B F E} \\
& \vec{q}=\overrightarrow{B F S-B F E}
\end{aligned}
$$

The normal vector of the base mat $\overrightarrow{\mathbf{n}}=\left(\mathrm{x}_{n}, \mathrm{y}_{n}, \mathrm{z}_{n}\right)$ can be calculated as follows:

$$
\overrightarrow{\mathbf{n}}=\vec{p} \times \vec{q}
$$

The normal vector $\overrightarrow{\mathbf{n}}$ can be normalized to a length of 1 . The rocking angle $a$ is sufficiently small that $\cos a \approx 1$, so $\left|z_{n}\right| \approx 1$. We can easily obtain the rocking angle in the $\mathrm{E}-\mathrm{W}$ direction, $\mathrm{a}_{x} \approx \mathrm{x}_{n}$, and the rocking angle in the $\mathrm{N}-\mathrm{S}$ direction, $\mathrm{a}_{y} \approx \mathrm{y}_{n}$.

\subsubsection{Calculation of the deformation of the superstructure}

The lateral fundamental-mode deformation of each floor can be calculated as follows (with a, $u_{i}$, and $u_{0}$ extracted using WWT):

$$
\begin{aligned}
R_{r i} & =H_{i} \times \mathrm{a} \\
q_{i 1} & =u_{i}-u_{0}-R_{r i}
\end{aligned}
$$

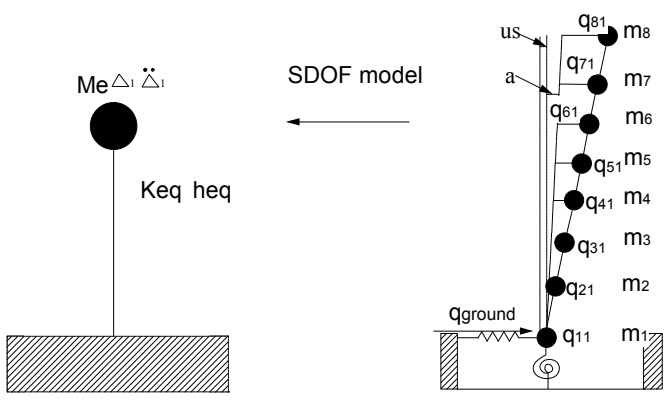

(a) SDOF mode I

(b) MDOF mode I

Fig. 2 MDOF model simplified to an SDOF model

where $R_{r i}$ is the rocking displacement of the $i$ th floor, $H_{i}$ is the height of the $i$ th floor, a is the rocking angle, $u_{i}$ is the measured lateral displacement of the $i$ th floor, $u_{0}$ is the measured displacement of the base floor, and $q_{i 1}$ is the deformation of the $i$ th floor for the fundamental mode, as shown in Figure 2(b).

In fact, only the motions of the first floor $\left(\mathrm{u}_{1}\right)$, the second floor $\left(u_{2}\right)$, the fifth floor $\left(u_{5}\right)$ and the roof floor $\left(u_{8}\right)$ were measured. It is reasonably assumed that the fundamental mode is dominant, so we need to calculate the motions of the other floors as follows.

$$
\begin{aligned}
& u_{3}=\frac{h_{2}}{h_{2}+h_{3}+h_{4}}\left(u_{5}-u_{2}\right)+u_{2} \\
& u_{4}=\frac{h_{2}+h_{3}}{h_{2}+h_{3}+h_{4}}\left(u_{5}-u_{2}\right)+u_{2} \\
& u_{6}=\frac{h_{5}}{h_{5}+h_{6}+h_{7}}\left(u_{8}-u_{5}\right)+u_{5}
\end{aligned}
$$




$$
u_{7}=\frac{h_{5}+h_{6}}{h_{5}+h_{6}+h_{7}}\left(u_{8}-u_{5}\right)+u_{5}
$$

where $h_{i}$ is the height of the $i^{\text {th }}$ floor. The properties and motions of the MDOF system are summarized in Table 2.

Table 2 Masses, fundamental displacements and heights corresponding to floors of the MDOF system

\begin{tabular}{|c|c|c|c|c|}
\hline $\mathrm{i}$ & $\begin{array}{c}\text { Mass } m_{i} \\
\left(10^{6} \mathrm{~kg}\right)\end{array}$ & $u_{i}(\mathrm{~m})$ & $q_{i 1}(\mathrm{~m})$ & $H_{i}(\mathrm{~m})$ \\
\hline 8 & 1.12 & $u_{8}$ & $q_{81}$ & 34 \\
\hline 7 & 0.74 & $u_{7}$ & $q_{71}$ & 28.9 \\
\hline 6 & 0.77 & $u_{6}$ & $q_{61}$ & 25.2 \\
\hline 5 & 0.93 & $u_{5}$ & $q_{51}$ & 21.5 \\
\hline 4 & 0.78 & $u_{4}$ & $q_{41}$ & 17.8 \\
\hline 3 & 0.78 & $u_{3}$ & $q_{31}$ & 14.1 \\
\hline 2 & 0.84 & $u_{2}$ & $q_{21}$ & 10.3 \\
\hline 1 & 1.26 & $u_{1}$ & $q_{11}$ & 6 \\
\hline
\end{tabular}

\section{Methodology and evaluation strategy}

\subsection{Seismic performance curve $\left(S_{a}-S_{d} \text { curve }\right)^{14)}$}

For the BRI annex building, the representative displacement $S_{d}$ was calculated using the deformation of the superstructure (Equation (5a)). The base shear force coefficient $S_{a}$ was calculated using Equation (5b). The base shear force $Q_{B}$ was calculated using Equation (7).

$$
\begin{aligned}
& S_{d}=\Delta_{1} \cdot \frac{\sum m_{i}}{M_{e}} \\
& S_{a}=\frac{Q_{B}}{M_{e}} \\
& \Delta_{1}=\frac{\sum m_{i} \cdot q_{i 1}}{\sum m_{i}} \\
& Q_{B}=\sum m_{i} \cdot \ddot{u}_{i} \\
& M_{e}=\frac{\left(\sum m_{i} \cdot q_{i 1 \max }\right)^{2}}{\sum m_{i} \cdot q_{i 1 \max ^{2}}}
\end{aligned}
$$

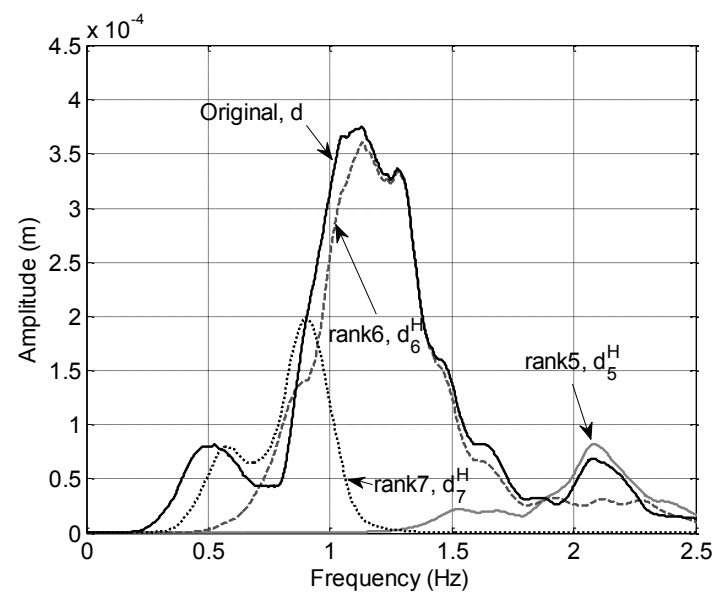

Fig. 3 Fourier spectrum of each component of the roof floor displacement for the 2011 off the Pacific Coast of Tohoku Earthquake in N-S direction
$M_{e}$ is the equivalent mass corresponding to the fundamental mode. We assumed that $M_{e}$ remained unchanged during a single earthquake and can be calculated (using equation (8)) from the maximum response points $\left(q_{i 1 \max }\right)$ of the fundamental mode response. Mass ratios $M_{e} / \sum m_{i}$ in the range of 0.72 to 0.76 were calculated for the earthquakes considered in this paper.

The relationship between $S_{a}$ and $S_{d}$ (for the peak response points, for which the damping effect is zero) can be expressed as follows, with $\omega_{f}$ denoting the fundamental circular frequency of the superstructure.

$$
S_{a}=\omega_{f}^{2} \cdot S_{d}
$$

The fundamental response $\left(q_{i 1}\right.$; see Figure $\left.2(\mathrm{~b})\right)$ is calculated using the WTT technique. KOICHI KUSUNOKI \& MASAOMI TESHIGAWARA $^{9)}$ have presented the method for using WTT to calculate the fundamental response. As Figure 3 shows, the original response can be decomposed into components that contain different frequency range signals). Rank6 and Rank7 reflect the fundamental response of the building to the earthquake that occurred at 2011/03/11/14:46. This fundamental response can be used to calculate the $S_{a}-S_{d}$ curve (equation (5)). A performance skeleton curve that reflects changes in the seismic performance from small responses to the maximum response can then be obtained ${ }^{10)}$, as shown in Figure 4.

3.2 Damage evaluation strategy using the $S_{a}-S_{d}$ curve

One of the objectives of this research was to use the $S_{a}-S_{d}$ curve to determine whether the building was damaged in past earthquakes. $S_{a}-S_{d}$ curves for the building for strong earthquakes were calculated using WWT and SDOF model theory (Figure 6 and Figure 7). However, there are two problems associated with using $S_{a}-S_{d}$ curves for damage detection: (1) it is difficult to determine the initial stiffness of the $S_{a}-S_{d}$ curve and (2) the velocity effect (the damping force) is contained in the $S_{a}-S_{d}$ curve. To overcome these problems, we established the following analysis strategy.

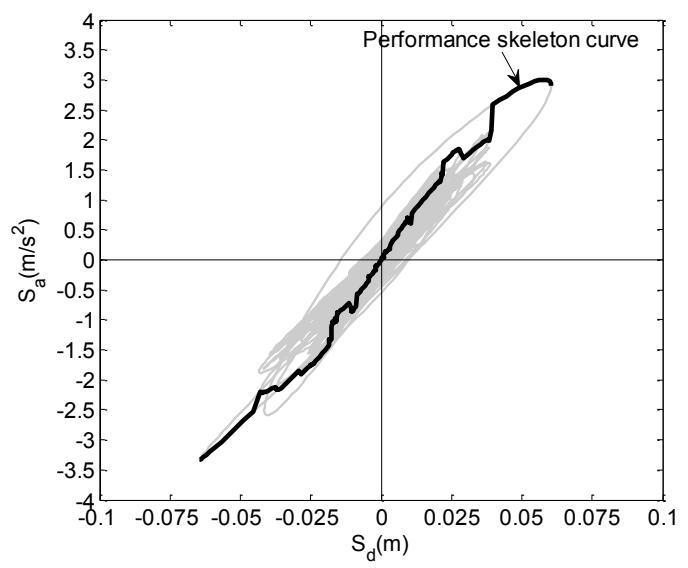

Fig. 4 Performance curve using Rank6 and Rank7 for Figure 3 as the fundamental response 


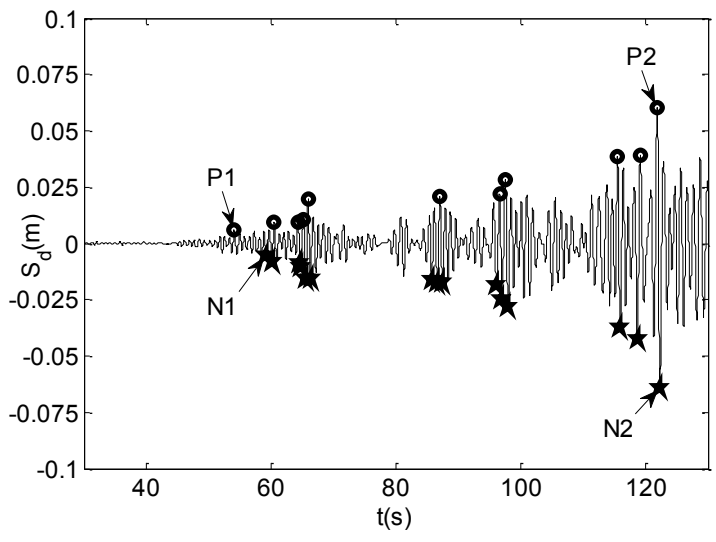

(a) Peak response points

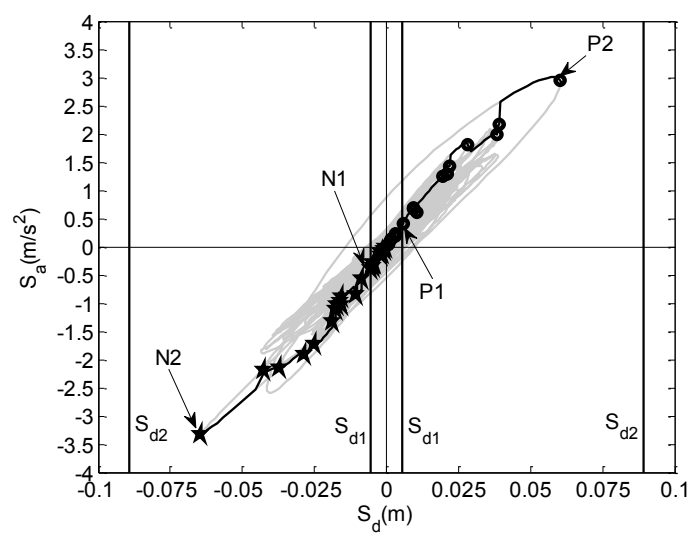

(b) Peak response points in the $\mathcal{S}_{-}-\mathcal{S}_{d}$ curve

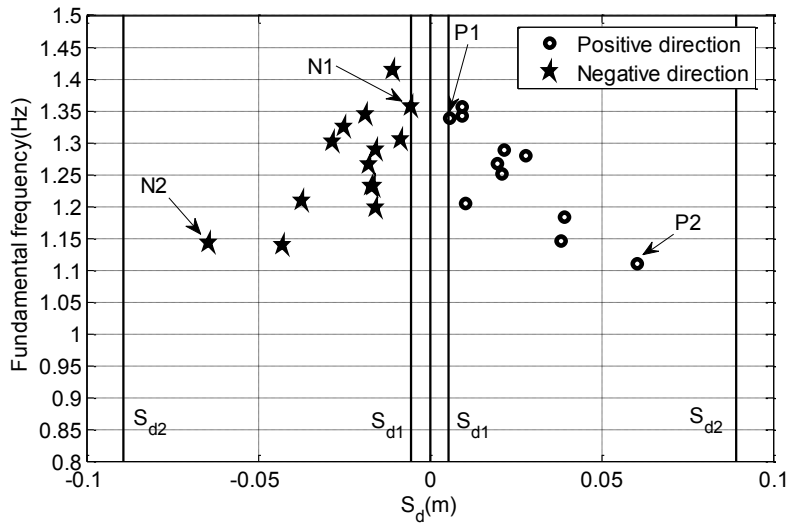

(c) Fundamental frequencies for the peak response points

Fig. 5 Damage assessment using the $\mathcal{S}_{a}-\mathcal{S}_{d}$ curve for the 2011 earthquake off the Pacific Coast of Tohoku Earthquake in $\mathrm{N}-\mathrm{S}$ direction

Table 3 Deformation level for the $S_{a}-S_{d}$ curve of the BRI annex building

\begin{tabular}{|c|c|c|}
\hline Level $(i)$ & 1 & 2 \\
\hline$D_{a i}(\mathrm{rad})$ & $\frac{1}{3200}$ & $\frac{1}{200}$ \\
\hline \multicolumn{2}{|c|}{ Height of the building $(\mathrm{m})$} & 28 \\
\hline$S_{d i}\left(10^{-3} \mathrm{~m}\right)$ & 5.6 & 89.1 \\
\hline
\end{tabular}

Step 1: Calculate the performance skeleton curve $\left(S_{a}-S_{d}\right.$ curve) using earthquake response measurement data collected during the earthquake, according to the method described in section 3.1.

Step 2: Define the two deformation levels shown in Table 3, $1 / 3200$ and $1 / 200$, where $D_{a i}$ is the drift angle of the superstructure and $S_{d i}$ is the corresponding representative displacement (calculated using equation (5a)). The minimum acceleration recorded by the accelerometers in the building was 1 $\mathrm{Gal}^{11)}$; therefore, the drift angle $1 / 3200 \mathrm{rad}\left(S_{d 1}=0.0056 \mathrm{~m}\right.$ for the building) is accurate and sufficiently small for the first level. The second-level 1/200 rad is larger than the maximum response for the earthquake shown in Figure 8 (for example, the maximum $S_{d}$ is $0.065 \mathrm{~m}$, which is less than $S_{d 2}=0.0891 \mathrm{~m}$ ).

Step 3: Select the peak response points inside or outside the deformation level $1\left(S_{d 1}\right)$ as the "initial points"-for example, N1 and P1 in Figure 5. The maximum peak response points (N2 and P2 in Figure 5) are selected as the "final points". The fundamental frequencies of the "initial points" and the "final points" are compared to assess whether damage occurred. As Figure 5(c) shows, the fundamental frequency decreased from approximately $1.35 \mathrm{~Hz}$ to approximately $1.1 \mathrm{~Hz}$, which means that earthquake damage occurred.

In this research, some large earthquakes (E-W direction: X01-X11, N-S direction: Y01-Y04, YA-YD and Y08-Y11; see Figure 8) with larger $S_{d}$ values than those of the neighborhood earthquakes were studied using the damage evaluation strategy mentioned above.

\section{Results and analysis}

Using the $S_{a}-S_{d}$ curve evaluation strategy described in section 3.2, $S_{a}-S_{d}$ curves for several strong earthquakes were developed and are shown in Figure 6 (E-W direction) and Figure 7 (N-S direction). The fundamental frequencies calculated using the "initial points" (for example, N1 and P1 defined in Figure 5) and "final points" (for example, N2 and P2 defined in Figure 5) of the $S_{a}-S_{d}$ curve (where "Positive direction" refers to the points in the positive direction and "Negative direction" refers to the 


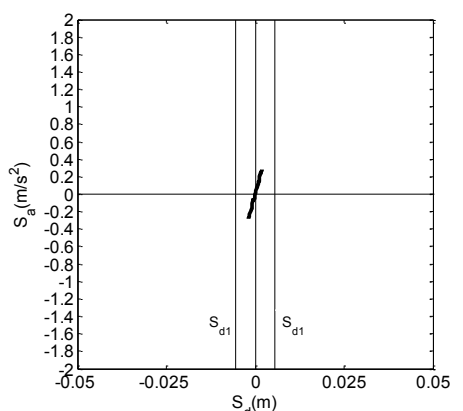

(a) $\mathrm{X01}$

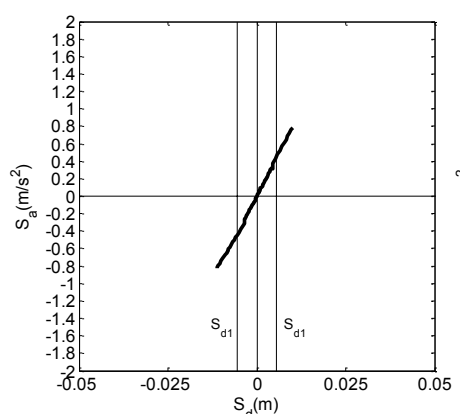

(b) $\times 07$

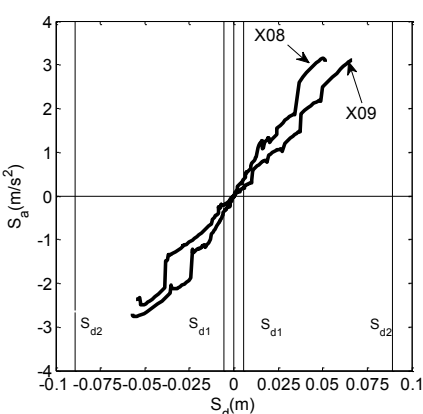

(c) X08 and X09

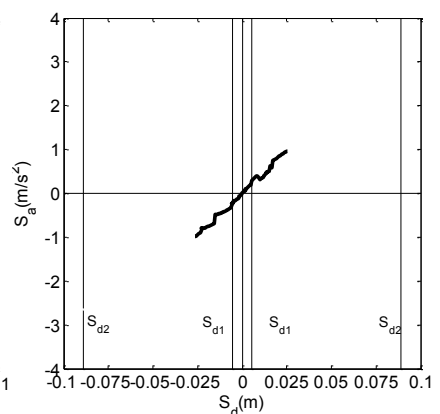

(d) $\times 10$

Fig. 6 Comparison of $S_{a}-S_{d}$ curves in the E-W direction

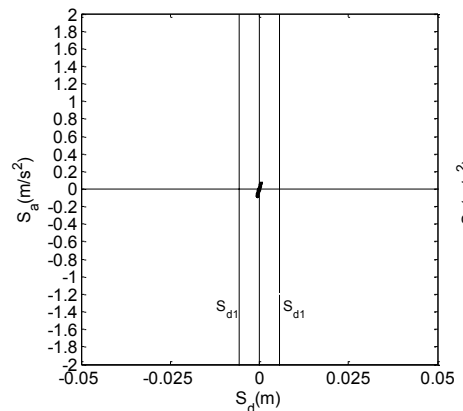

(a) Y01

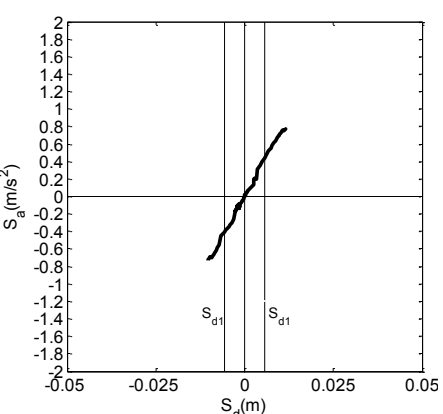

(b) YD

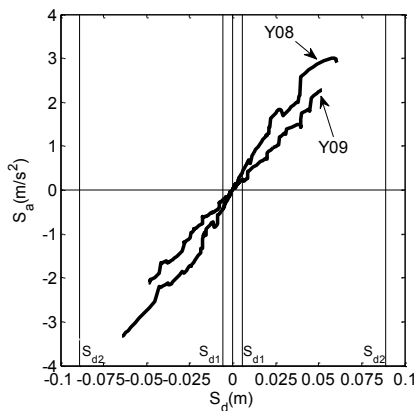

(c) Y08 and Y09

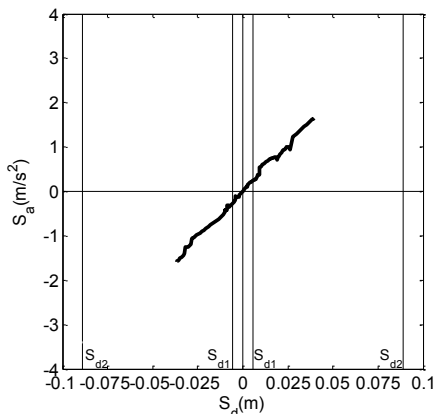

(d) $\mathrm{Y} 10$

Fig. 7 Comparison of $\mathcal{S}_{a}-\mathcal{S}_{d}$ curves in the $\mathrm{N}$-S direction

points in the negative direction) are summarized in Figure 9. For smaller earthquakes whose maximum representative displacement $S_{d}$ is less than $S_{d 1}$ (for example, X01-X04, Y01-Y03, YA, and YB), we calculated the fundamental frequency using the maximum response points only. For larger earthquakes (such as X05-X11, Y04, YC, YD, and Y08-Y11), we used the points ("initial points" and "final points") described previously. However, for the earthquake X09 or Y09, which was an aftershock that occurred approximately 30 minutes after the earthquake X08 or Y08, only the maximum response points were used to calculate the fundamental frequency.

For the $\mathrm{E}-\mathrm{W}$ direction, we found that earthquake damage might have occurred in earthquake X08 (X09 was the aftershock of X08. The fundamental frequency decreased from approximately $1.30 \mathrm{~Hz}$ to $1.09 \mathrm{~Hz}$ (see Figure 9 (a), X08 and X09), as shown by the $S_{a}-S_{d}$ curve and Figure 6 (c) (X08 and X09). We also found that no severe earthquake damage occurred in the other earthquakes considered, such as X01-X07, X10, and X11.

For the N-S direction, we found that earthquake damage occurred in earthquake Y08 (the fundamental frequency decreased from approximately $1.35 \mathrm{~Hz}$ to $1.05 \mathrm{~Hz}$ (see Figure 9(b), Y08 and Y09 and Figure 7(c), Y08 and Y09). We also found that no severe earthquake damage occurred in the other earthquakes considered, such as Y01-Y04, YA-YD, Y10, and Y11.

Overall, the fundamental frequency decreased from approximately $1.9 \mathrm{~Hz}$ to approximately $1 \mathrm{~Hz}$ (a decrease of approximately $47.4 \%$ ), but the decrease in the fundamental frequency caused by earthquake damage was only approximately $11.1 \%$ in the $\mathrm{E}-\mathrm{W}$ direction and $16.32 \%$ in the $\mathrm{N}-\mathrm{S}$ direction. For some smaller earthquakes (X01-X07, X10, and X11; Y01-Y04, YA-YD, Y10, and Y11), the $S_{a}-S_{d}$ curves (Figures 6(a) and (b) and Figures 7 (a) and (b)) are linear. However, the $S_{a}-S_{d}$ curves for these earthquakes show that the seismic capacity of the superstructure decreased substantially, as shown in Figure 9. The fundamental frequency decreased from approximately 1.9 $\mathrm{Hz}$ to approximately $1.36 \mathrm{~Hz}$ in the E-W and $1.30 \mathrm{~Hz}$ in the N-S direction between 1998 and 2010 (as Figure 6 (a)(b) and Figure 7(a)(b) show, the $S_{a}-S_{d}$ curves are linear), which is consistent with the results calculated by Kashima ${ }^{11}$. We conclude that the decrease in the superstructure stiffness (the fundamental frequency) over this time period was not caused by severe earthquake damage but other unknown reasons such as material aging.

\section{Conclusions}

The seismic performance curve $\left(S_{a}-S_{d}\right.$ curve $)$ concept was used to evaluate earthquake damage in a real SRC building using the evaluation strategy described in this paper. SSI effects (rocking motion and swaying motion) were eliminated in the calculation of the representative displacement $S_{d}$, and fundamental responses were extracted using wavelet transform technology. The conclusions reached can be summarized as follows.

(1) Changes in $S_{a}-S_{d}$ curves (which reflect changes in 


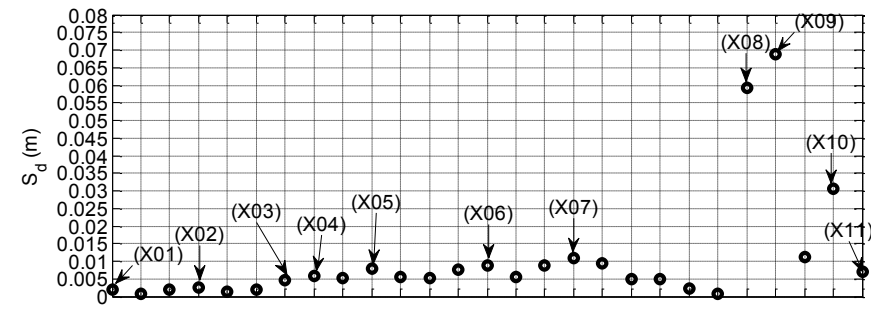

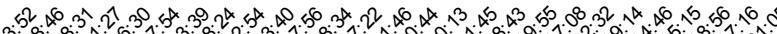

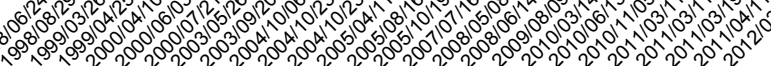

(a) E-W direction $S_{d}$

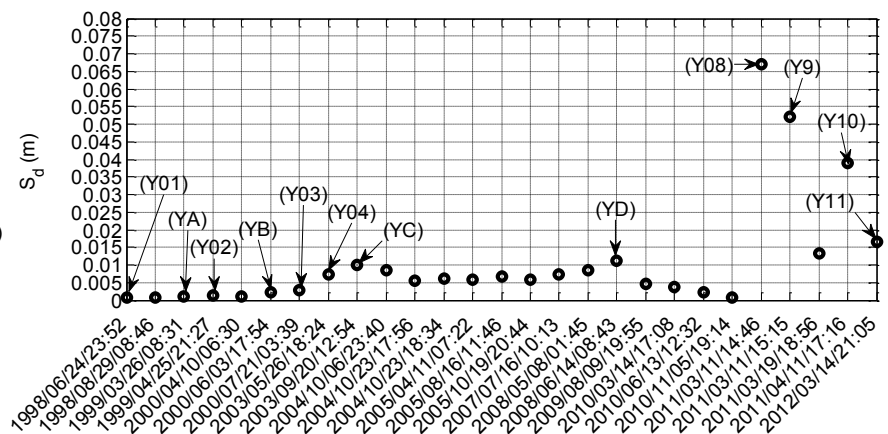

(b) $\mathrm{N}-\mathrm{S}$ direction $S_{d}$

Fig. $8 S_{d}$ for 27 strong earthquakes

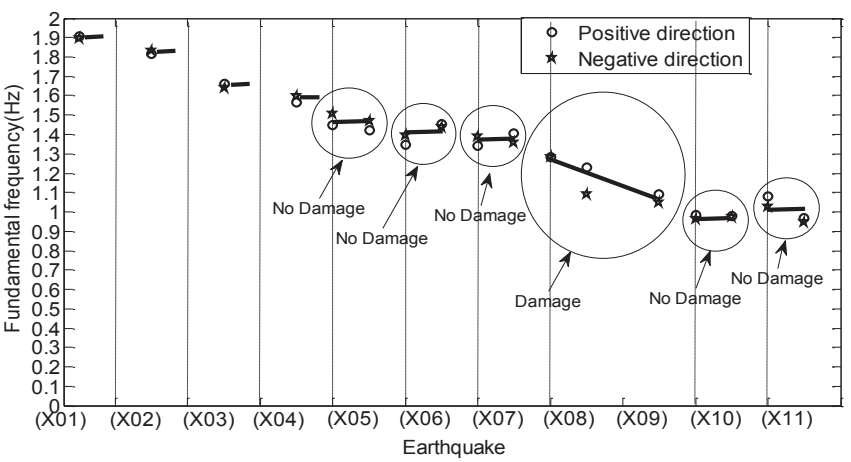

(a) Damage judgment in E-W direction

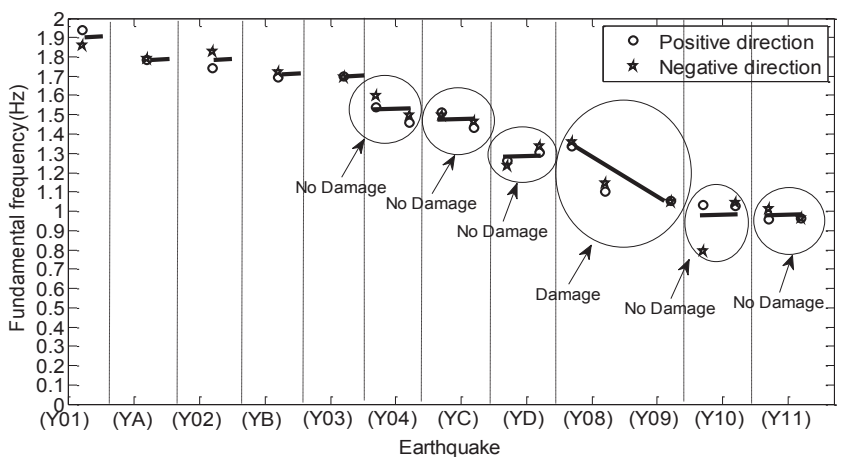

(b) Damage judgment in N-S direction

Fig. 9 Evaluation of $\mathcal{S}_{a}-\mathcal{S}_{d}$ curves

seismic capacity) can be observed using measurement data. The fundamental frequency of the BRI annex building decreased from approximately $1.90 \mathrm{~Hz}$ to approximately $1 \mathrm{~Hz}$ between 1998 and 2012. This decrease was mainly caused by a decrease in the seismic capacity of the superstructure. The contribution of earthquake damage to the decrease in the fundamental frequency was approximately $11.1 \%$ in the $\mathrm{E}-\mathrm{W}$ direction and $16.32 \%$ in the $\mathrm{N}-\mathrm{S}$ direction. This damage occurred during the earthquake that occurred in 2011 off the Pacific Coast of Tohoku. Although no severe earthquake damage occurred between 1998 and 2010, the fundamental frequency of the superstructure decreased substantially (the superstructure stiffness decreased to approximately $50 \%$ of its initial value).

(2) The damage evaluation method based on the $S_{a}-S_{d}$ curve concept is simple and practicable. A simplified $S_{a}-S_{d}$ curve can help us understand changes that occur in the seismic capacity of a building in real time. Nevertheless, even though linearity and nonlinearity in $S_{a}-S_{d}$ curves can be observed, the initial stiffness of the curve is difficult to establish numerically. Therefore, the damage evaluation strategy presented in this paper is considerably appropriate for cases in which the story drift angle is sufficiently large (for example, when the story drift angle of the building is greater than 1/3200 rad).

The evaluation method described in this paper needs to be adapted to other types of buildings, and its accuracy needs to be refined in the future. The building considered in this study is an 8-story SRC building for which the applicability of the SDOF model is reasonable. For high-rise buildings and irregular buildings, much more complex mechanisms (such as high-mode effects, torsional effects) will influence the earthquake responses. Therefore, the applicability of the $S_{a}-S_{d}$ curve method should be evaluated for these types of buildings. In addition, it is possible to determine the damage points using the $S_{a}-S_{d}$ curve, and the residual displacements also need to be studied further in the future.

\section{Acknowledgements}

This research was made possible by the Building Research Institute (BRI) of Japan supplying important original measurement data. The WTT program used in this research was supplied by Professor Koichi KUSUNOKI of The University of Tokyo.

\section{References}

1) Peter C. Chang, Alison Flatau and S. C. Liu: Review Paper: Health Monitoring of Civil Infrastructure, Structural Health Monitoring, Vol. 2(3), pp. 257-267, 2003.

2) M. D. Trifunac, S. S. Ivanovic, and M. I. Todorovska: Apparent periods of a building. I : Fourier analysis, Journal of Structural Engineering, Vol. 127, No. 5, pp. 517-526, 2001.

3) John F. Clinton, S. Case Bradford, Thomas H. Heaton and Javier Favela: The Observed Wander of the Natural Frequencies in a Structure, Bulletin of the Seismological Society of America, Vol. 96, No. 1, pp. 237-257, 2006. 2. 
4) Zbigniew Zembaty, Marcin Kowalski and Stanislav Pospisil: Dynamic identification of a reinforced concrete frame in progressive states of damage, Engineering Structures, Vol. 28, pp. 668-681, 2006.

5) Maria I. Todorovska, Mihailo D. Trifunac: Earthquake damage detection in the imperial Country Service Building I : The data and time-frequency analysis, Soil Dynamics and Earthquake Engineering, Vol. 27, pp. 564-576, 2007.

6) Maria I. Todorovska, Mihailo D. Trifunac: Earthquake damage detection in the imperial Country Service Building II : Analysis of novelties via wavelets, Structural Control and Health Monitoring, Vol. 17, pp. 895-917, 2010.

7) Maria I. Todorovska, Mihailo D. Trifunac: Earthquake damage detection in the imperial Country Service Building III: Analysis of wave travel times via impulse response functions, Soil Dynamics and Earthquake Engineering, Vol. 28, pp. 387-404, 2008.

8) Maria I. Todorovska, M. Rahmani: Recent Advances in Wave Travel Time Based Methodology for Structural Health Monitoring and Early Earthquake Damage Detection in Buildings, $15^{\text {th }}$ World Conference of Earthquake Engineering, LISBOA, 2012.

9) Koichi KUSUNOKI, Ahmed Elgamal, Masaomi Teshigawara and Joel P. Conte: Evaluation of Structural Condition Using Wavelet Transforms, $14^{\text {th }}$ World Conference on Earthquake Engineering, Beijing, China, Paper No.609, 2008.10.

10)Manabu Kawamura, Koichi Kusunoki, Miho Yamashita, Yuki Kattori, Daiki Hinata, Miguel Augusto DIAZ FIGUEROA and Akira Tasai: Study of a New Method to Compute the Performance Curve of Real Structures with Acceleration Sensors in the case of SDOF System Structures, J. Struct. Constr. Eng. AIJ, No.688, pp.1061-1069, 2013.6.

11)Toshihide Kashima and Yoshikazu Kitagawa: Dynamic characteristics of a building estimated from strong motion records using evolution strategy, J. Struct. Constr. Eng., AIJ, No. 602, pp. 145-152, 2006.4.

12)Toshihide Kashima: Dynamic behavior of an eight-story SRC building examined from strong motion recordings, $13^{\text {th }}$ World Conference on Earthquake Engineering Vancouver, B. C., Canada, Paper No. 196, 2004.

13)Ali Niousha, Yukio Natio, Masao Kan, Atsushi Onouchi and Atsushi Tachibana: System Identification of a Nuclear Reactor Building Under Fixed Base Condition Using Measurement Data, J. Struct. Constr. Eng., AIJ, No. 583, pp. 69-76, 2004.9.

14)Koichi Kusunoki and Masaomi Teshigawara: A New Acceleration Integration Method to Develop a Real-Time Residual Seismic Capacity Evaluation System, J. Struct. Constr. Eng., AIJ, No. 569, pp. 119-126, 2003.7 . 


\section{和文要約}

\section{1. はじめに}

建築構造物の地震時の損傷評価は, 余震での二次災害の防止, 建 物の効率的な維持管理という観点から重要である。既往の研究では, 伝達関数の分析に基づく固有振動数や固有モード形といった構造物 の動特性の変化に着目した損傷評価法が主流である 1)。しかし，そ れらの手法では地震中の固有振動数の変化を捉えることができず,

構造物の損傷レベルを適切に判定することが難しい。

勅使川原, 楠ら 910) は, 限界耐力計算等で用いられている建物の 代表的な荷重変形関係である建物性能曲線に着目し，地震観測記録 から建物性能曲線を精度よく算定する方法について検討している。 本手法を用いて建物性能曲線を表示することで，地震中の建物の動 特性の変化を把握することができ, 迅速な残余耐震性能評価が可能 となることが期待される。本研究では, SRC 造 8 階建建築物の実観 測記録を用いて建物性能曲線を算定し，性能曲線を用いた損傷評価 の可能性について検討する。特に，動的相互作用や高次モードの影 響の排除する方法や，有意な建物性能曲線を算出する方法，時系列 的に見た建物性能曲線の変動から構造物の損傷を評価する方法につ いて検討している。

\section{2. 計測概要}

対象建物は，8 階建 SRC 造建築物である 11)12)。1998 年の竣工当 初から強震観測が行われており, 鹿島ら 1112)の研究により, ロッキ ング挙動がスウェイ挙動よりも大きいこと, 固有振動数は 2005 年 までに竣工時の $70 \%$ 程度まで低下していること, その低下の要因は 上部構造の剛性の変化であることが示されている。本研究では, 2012 年までに観測された強震記録を分析し, 時系列での動特性の変 化だけでなく，地震による損傷の有無についても明らかにする。

解析に用いる観測記録は, 2012 年までに記録された 1239 個の記 録のうち，比較的大きな応答を示す 27 個の記録とする。ロッキン グ挙動の影響を取り除くため, 最下階床位置の 3 点の計測記録から 2 次元的なロッキング応答を算定し, それを上部構造の応答記録か ら取り除いた。

\section{3. 性能曲線の算定方法}

代表加速度 $S_{a}$, 代表変位 $S_{d}$ は, 加速度記録で得られる変位分布 が建物の代表的なモードであると仮定することで, 式(7)のように得 られる。応答記録に含まれている高次モードやノイズの影響を排除 するため, ウェーブレット変換を用いる。ウェーブレット変換は, 記録を複数の周波数範囲（ランク）の成分に分割することができる ため, 主要な成分を含むランクのみを用いることで高次モードや， イズの影響を排除できる。

得られた性能曲線は, 多折れ線にモデル化することで構造物の動 特性の変化を把握する。本論文では, 計測機器の精度や, SRC 造構 造物の一般的な挙動に配慮して, 層間変形角レベルで, $R=1 / 3200$ までの応答を初期応答と仮定し, 初期応答の平均岡性と, 最大層間 変形角時の剛性を比較することで損傷レベルを判定する方法を提案 する。

\section{4. 解析結果}

建物性能曲線を算定した結果の一例を Fig. 6,7 に示す。また, 各 地震での初期剛性と最大層間変形角時剛性を比較した結果を Fig.9 に示す。 E-W 方向, N-S 方向とも, X08 地震時に損傷が生じたこと
が確認でき，その他の地震では損傷は確認されない。竣工時から 2012 年までに, 固有振動数が初期固有振動数 $1.9 \mathrm{~Hz}$ から $1.0 \mathrm{~Hz}$ ま で低下（約 $47 \%$ の低下）しているが，そのうち地震時の損傷による ものは E-W 方向で $11.1 \%, \mathrm{~N}-\mathrm{S}$ 方向で $16.3 \%$ と考えられる。建物性 能曲線からは, 上記以外の地震時の損傷は確認されないことから， 竣工当時からの固有振動数の低下は, 経年劣化等の要因が主要因と なっていると考えられる。

5. まとめ

（1）建物性能曲線から，固有振動数が $1.9 \mathrm{~Hz}$ から $1.0 \mathrm{~Hz}$ まで低下し ていることが確認された。また，そのうち地震時の損傷によるもの が約 11\%であることも確認された。

（2）建物性能曲線を用いることで，容易に建物の状態を把握するこ とができることが確認された。ただし，初期応答とみなす変形レ心゙ ルの設定には，より詳細な検討が必要である。

本対象建物は比較的低層の, 整形建物であるため, 適用性が高かっ た。今後は, 高層建物や非整形建物, 高次モードやねじれモードの 卓越する複雑な建物に対する適用可能性について検討する。

（2014年 3 月 5 日原稿受理，2014年 4 月21日採用決定） 